Review

\title{
An Intratracheal Instillation Bioassay System for Detection of Lung Toxicity Due to Fine Particles in F344 Rats
}

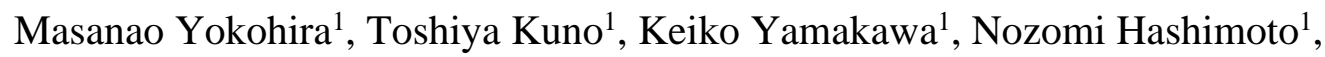 \\ Fumiko Ninomiya ${ }^{1}$, Satoshi Suzuki ${ }^{1}$, Kousuke Saoo ${ }^{1}$, and Katsumi Imaida ${ }^{1}$ \\ ${ }^{1}$ Onco-Pathology, Department of Pathology and Host-Defense, Faculty of Medicine, Kagawa University, 1750-1 \\ Ikenobe, Miki-cho, Kita-gun, Kagawa 761-0793, Japan
}

\begin{abstract}
It is an urgent priority to establish in vivo bioassays for detection of hazards related to fine particles, which can be inhaled into deep lung tissue by humans. In order to establish an appropriate bioassay for detection of lung damage after particle inhalation, several experiments were performed in rats using quartz as a typical lung toxic particle. The results of pilot experiments suggest that Days 1 and 28 after intratracheal instillation of $2 \mathrm{mg}$ of fine test particles in vehicle are most appropriate for detection of acute and subacute inflammatory changes, respectively. Furthermore, the BrdU incorporation on Day 1 and the iNOS level on Day 28 proved to be suitable end-point markers for this purpose. An examination of the toxicity of a series of particles was performed with the developed bioassay. Although some materials, including nanoparticles, demonstrated toxicity that was too strong for sensitive assessment, a ranking order could be clarified. The bioassay thus appears suitable for rapid hazard identification with a possible ranking of the toxicity of various particles at single concentrations. (J Toxicol Pathol 2009; 22: 1-10)
\end{abstract}

Key words: particulates, respiratory toxicology, fine particles, intratracheal instillation, rat, bioassay

\section{Introduction}

There are many toxicants in our environment, including air pollutants. Human investigations focusing on concentrated ambient particles have shown acute lung inflammation and changes in both blood indices and heart rate $^{1}$. It is an urgent priority to establish in vivo bioassays for the detection of hazards related to fine particles, which can be inhaled into deep lung tissue by humans.

In quartz dust-exposed construction workers, obstructive and restrictive loss of lung function has been detected $^{2}$, as has chronic obstructive pulmonary disease $(\mathrm{COPD})^{3,4}$. These are associated with inflammatory cell responses characterized by alveolitis with recruitment of inflammatory cells, particularly neutrophils, and may result in pulmonary fibrosis and impaired lung function ${ }^{5}$. Intratracheal instillation (i.t.) of quartz into rats produces an inflammatory reaction followed by histological changes characteristic of lung fibrosis ${ }^{6}$, similar to the above noted human conditions. Borm et al. reported a no observed adverse effect level (NOAEL) for quartz of between 0.03

Received: 21 August 2008, Accepted: 4 November 2008 Mailing address: Katsumi Imaida, Onco-Pathology, Department of Pathology and Host-Defense, Faculty of Medicine, Kagawa University, 1750-1 Ikenobe, Miki-cho, Kita-gun, Kagawa 761-0793, Japan TEL: 81-87-891-2111 FAX: 81-87-891-2112

E-mail: imaida@med.kagawa-u.ac.jp and $0.13 \mathrm{mg} / \mathrm{m}^{3}$ (40 year exposure) ${ }^{7}$ based on an autopsy study for humans showing that lung burdens between 0.7 and $1.7 \mathrm{~g}$ of quartz are associated with macules only and not simple coal worker's pneumoconiosis ${ }^{8}$.

In order to establish an appropriate bioassay for detection of lung damage after particle inhalation, several experiments were performed in rats using quartz as a typical particle lung toxicant. Each lung lobe was examined histopathologically and immunohistochemically. Histopathologically, neutrophil infiltration in the walls and in the spaces of alveoli, pulmonary edema, pulmonary fibrosis, macrophage infiltration in the alveoli, restructuring of walls of the alveoli and granuloma production were all assessed (Fig. 1). These parameters of inflammatory change were scored as follows: 0 , no change; 1 , weak; 2 , moderate; and 3, severe. For objective assessment, 5-bromo-2'-deoxyuridine (BrdU) incorporation and expression of inducible NO synthase (iNOS) were also immunohistochemically examined (Fig. 2). Antibodies specific for BrdU provide a sensitive method for detecting DNA replication for DNA repair and cell proliferation in situ ${ }^{9}$, while iNOS is associated with development of lung damage, inflammation, granulomas and fibrosis induced by inhalation of silica ${ }^{10}$. These markers are generally associated with inflammation and may increase at different times after particle inhalation.

In this review, we summarize some pilot data from a sequential analysis study, a dose response study and a vehicle assessment study conducted to establish a bioassay 

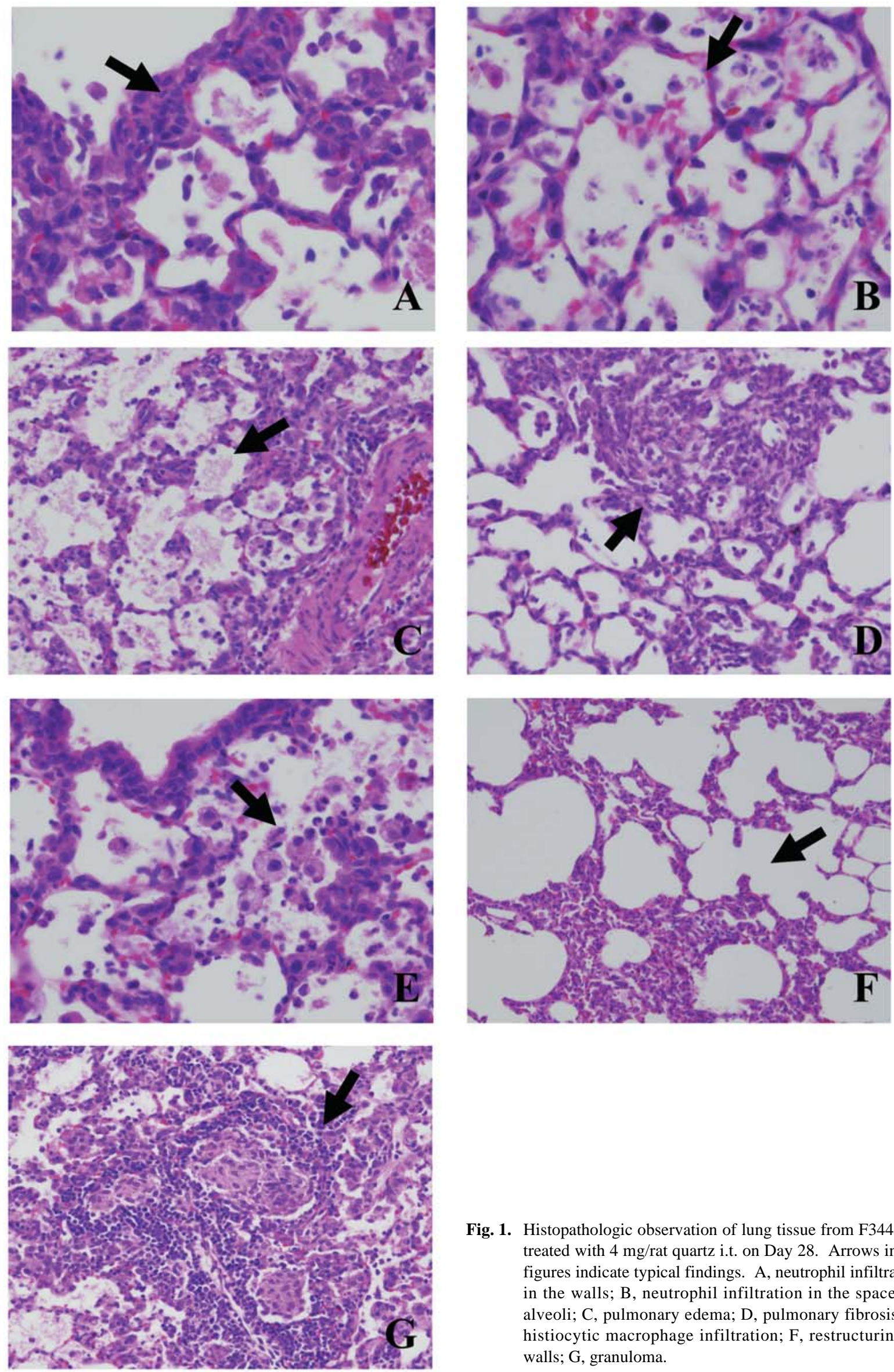

Fig. 1. Histopathologic observation of lung tissue from F344 rats treated with $4 \mathrm{mg} / \mathrm{rat}$ quartz i.t. on Day 28. Arrows in the figures indicate typical findings. A, neutrophil infiltration in the walls; $\mathrm{B}$, neutrophil infiltration in the spaces of alveoli; C, pulmonary edema; D, pulmonary fibrosis; E, histiocytic macrophage infiltration; F, restructuring of walls; G, granuloma. 

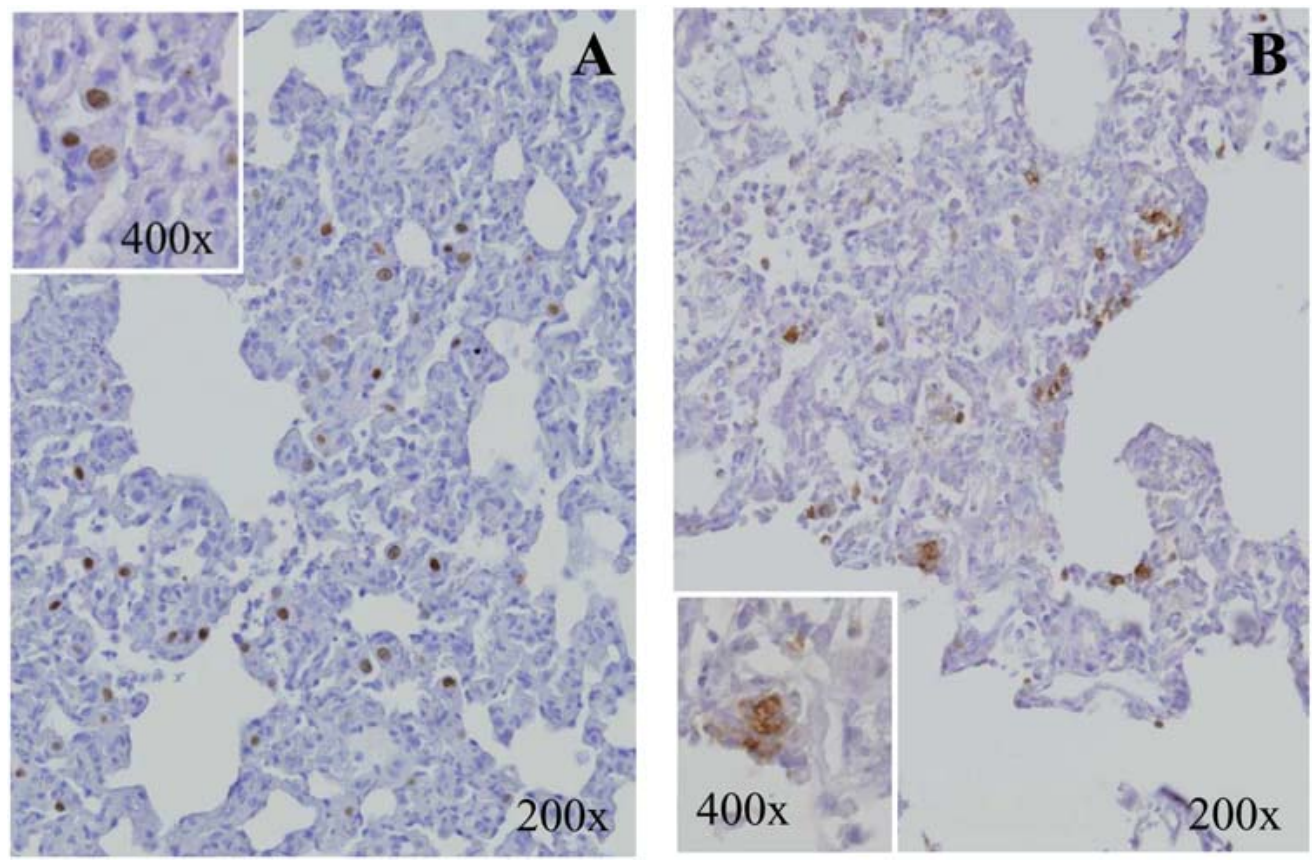

Fig. 2. Immunohistochemical observation of BrdU and iNOS. A, immunostaining of BrdU on Day 1; B, immunostaining of iNOS on Day 28 after i.t. of $4 \mathrm{mg} / \mathrm{rat}$ quartz.

model featuring instilled quartz as the positive control. Finally, the toxicity of a series of different particle types, including nanoparticles and diesel exhaust particles, was also tested with our new bioassay.

\section{Sequential Analysis Study}

In order to establish an appropriate bioassay for detection of lung damage after fine particle inhalation, sequential histopathological changes were examined after i.t. of quartz with a particle diameter of not more than $7 \mu \mathrm{m}$ (DQ-12, Deutzche Montan Technologie, GmbH, Germany, $4 \mathrm{mg} / \mathrm{rat}$ ), as a typical lung toxic agent, in F344 male rats ${ }^{11}$.

A total of 50, 10-week-old animals were separated into two groups (Fig. 3). Twenty-five rats were exposed to the material suspended in saline $(0.2 \mathrm{ml})$ using a specially designed aerolizer (Penn Century, PA, USA), and subgroups were sacrificed $1,3,7,14$ and 28 days thereafter. The remaining 25 rats were exposed by i.t. to saline $(0.2 \mathrm{ml})$ as a control group and were sacrificed on the same days. Both groups received intraperitoneal injections (i.p.) of $100 \mathrm{mg} / \mathrm{kg}$ b.w. BrdU before sacrifice and underwent assessment of lung histopathology with immunohistochemical demonstration of BrdU, iNOS and matrix metalloproteinase3 (MMP-3, employed as a marker of fibrotic change).

In this experiment, after quartz treatment, lungs on Day 1 demonstrated acute inflammatory changes with neutrophil infiltration, while granulation-like changes with giant cells and macrophages in the alveoli were evident on Day 28. The results were generally in line with pronounced accumulation of neutrophils in alveoli ${ }^{12}$. Furthermore, the numbers of BrdU positive cells were found to gradually decrease after

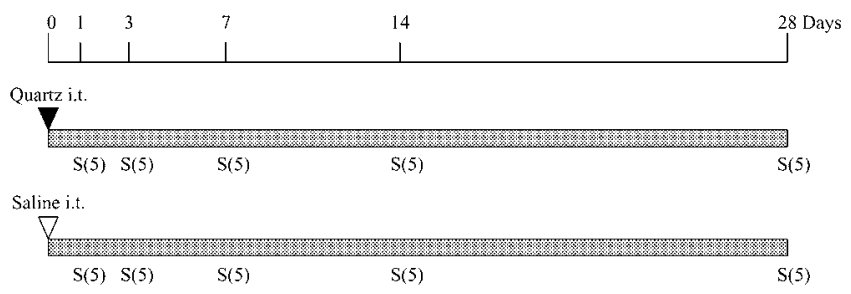

Fig. 3. Experimental design for the sequential analysis study. A total of 50,10-week-old animals were separated into two groups. $\boldsymbol{\nabla}$, i.t. of $4 \mathrm{mg} /$ rat quartz suspended in $0.2 \mathrm{ml}$ saline. $\nabla$, i.t. of $0.2 \mathrm{ml}$ saline (control). S(5), sacrifice of 5 rats.

the initial peak on Day 1. Monoclonal antibodies specific for BrdU provide a sensitive method for detecting DNA replication for DNA repair and cell proliferation in situ . The numbers and areas of iNOS positive cells, in contrast, increased with time up to Day 28, i. e., throughout the experimental period. Previous studies show that iNOS is expressed by many cells within the lung parenchyma after exposure to various inflammatory stimuli ${ }^{13,14}$ and is also associated with neovascularization and proliferation ${ }^{15}$. Furthermore, iNOS activity in primary tumor tissues in cases of fresh human gynecological and breast cancers correlates positively with the tumor grade ${ }^{16,17}$. Generation of oxidants and nitric oxide, in particular, is temporally and anatomically associated with development of lung damage, inflammation, granulomas and fibrosis induced by inhalation of silica ${ }^{10}$.

The results suggest that Days 1 and 28 after intratracheal instillation of fine test particles are the most appropriate day for detection of acute and subacute inflammatory changes, respectively. Furthermore, BrdU on 
Day 1 and iNOS on Day 28 proved to be suitable end-point markers for this purpose.

For further validation of the sequential analysis, the toxicities of fine particles from various materials (quartz, hydrotalcite, potassium octatitanate, palladium oxide and carbon black) were examined using our in vivo bioassay with a special focus on the correlations between immunohistochemical and histopathological findings ${ }^{18}$. A total of 108, 10-week-old F344/DuCrj male rats were randomly divided into 8 groups (Fig. 4). Groups 1 to 5 underwent i.t. of the 5 test particles ( $4 \mathrm{mg} / \mathrm{rat}$ ), quartz, hydrotalcite, potassium octatitanate, palladium oxide and carbon black, respectively, suspended in $0.2 \mathrm{ml}$ vehicle (saline or $10 \%$ propylene glycol and $1 \%$ sodium carboxymethyl cellulose in saline: PG-CMC) with an aerolizer, and subgroups of 7 rats were sacrificed on Days 1 and 28 thereafter. Groups 6 and 7 were similarly exposed to saline and PG-CMC, respectively, as vehicle controls, while group 8 was maintained untreated. Histopathological changes and immunohistochemically assessed BrdU labeling indices and iNOS levels were applied as end points.

From the scoring indices generated by the comparative histopathological and immunohistochemical assessment (Fig. 5), the quartz treated group demonstrated severe toxicity, while the other particle treated groups all exhibited relatively mild toxic effects. Biochemical analyses at different time points following instillation of different materials earlier demonstrated that all of the exposed groups developed granulomas. Alveolar lipoproteinosis and pulmonary fibrosis were most severe in the quartz treated lungs and progressed with time ${ }^{19}$. The present results for BrdU immunohistochemistry demonstrated that, in all groups, proliferation was enhanced on Day 1 due to particle exposure but had returned to almost normal values by Day 28. In contrast, iNOS values were higher at the latter time point in the quartz and hydrotalcite groups. This time course of change in iNOS expression may be important in terms of toxicity assessment, and it may be necessary to examine a later time point (estimated to be about 8 months) after i.t. to clarify the influence of change with time. MMP-3 may degrade cell matrix materials in areas with active inflammation and fibrosis ${ }^{20}$. However, in this experiment, expression of MMP-3 was not associated with any of the subchronic changes, such as granulation, collagenization or fibrosis, after particle instillation. Another marker for fibrosis is therefore needed.

Generally, bronchoalveolar lavage (BALF) with markers of inflammation is often used to assess the lung toxicity of instilled test particles in rats ${ }^{21-23}$. In our experiment, histopathological findings and 3 different immunohistochemical markers (BrdU, iNOS and MMP-3) were selected and were scored in order to provide an objective assessment. Compared with BALF, this approach has the advantage of allowing detailed investigation of lung damage; it also has disadvantages, for example, in that rats must be sacrificed at each time point and sequential changes cannot be followed at the individual animal level.

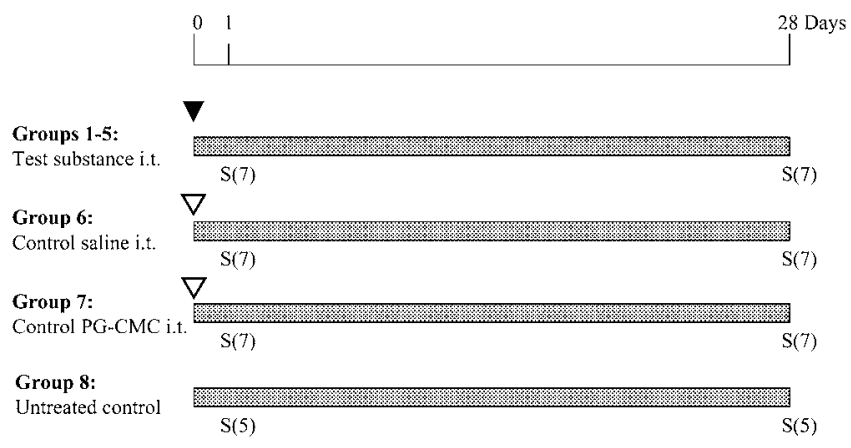

Fig. 4. Experimental design for validation of the sequential analysis study. A total of 108, 10-week-old F344/DuCrj male rats were randomly divided into 8 groups. $\boldsymbol{\nabla}$, i.t. of $4 \mathrm{mg} /$ rat test substances, quartz, hydrotalcite, potassium octatitanate, palladium oxide and carbon black, suspended in $0.2 \mathrm{ml}$ saline or PG-CMC for carbon black. $\nabla$, i.t. of $0.2 \mathrm{ml}$ saline or 0.2 ml PG-CMC (control). S(7) or S(5), sacrifice of 7 or 5 rats.

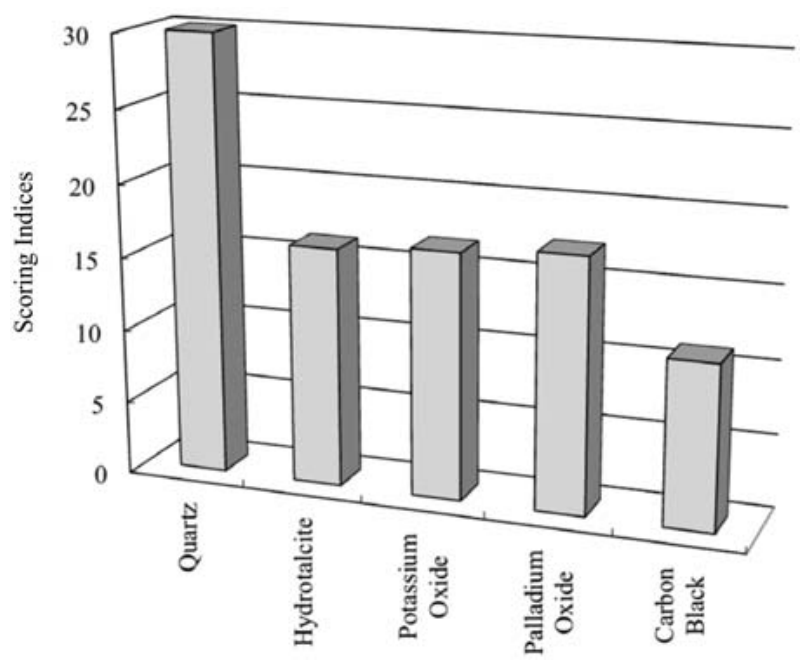

Fig. 5. Scoring indices from the comparative histopathological and immunohistochemical assessment. The quartz-treated group demonstrated severe toxicity, while the other hydrotalcite, potassium octatitanate, palladium oxide and carbon blacktreated groups all exhibited relatively mild toxicity. This figure is modified version of that of Yokohira et al. $2007^{16}$.

The present study featured comparison of 5 different particles in one experiment using an in vivo bioassay model. There has hitherto been no data available concerning instillation or inhalation of hydrotalcite and palladium oxide. TISMO has been evaluated after inhalation ${ }^{24}$, and similarly, quartz and carbon black have been evaluated after inhalation and instillation ${ }^{25-28}$. In this experiment, quartz exerted much stronger toxicity than the other test particles, which did not greatly differ in their effects. One of the probable reasons for this was the dose configuration. The dose of $4 \mathrm{mg} / \mathrm{rat}$ of quartz instilled directly into the trachea in this experiment was selected based on data reported previously ${ }^{29}$, and dose dependence at higher levels is currently being investigated in 
our laboratory.

There are biologically different responses to inhalation and instillation ${ }^{30}$, but given the rapidity with which different particles can enter the lung, acute effects may be most important. The advantages of assessment of particle toxicity using in vivo bioassays such as i.t. have been stressed ${ }^{23}$. The i.t. method is clearly useful for detection of acute and subacute pulmonary particle effects using a histopathological scoring system and markers like BrdU and iNOS.

\section{Dose Response Study}

The dose of $4 \mathrm{mg}$ quartz used by Mercer et al. (2003) $)^{29}$ is too large to allow for assessment of slight changes. In fact, the toxicities of the 5 materials in our validation experiment were found to be only high (quartz only) or low (other particles), with no intermediate toxicity. In many reports of toxicity assessment of fine particles using quartz as a positive control, the doses employed have been less than 4 $\mathrm{mg}^{21,31-33}$. In our study, a total of 40, 10-week-old male F344 rats were randomly separated into 4 groups of 10 rats each (Fig. 6) and exposed by intratracheal instillation to $4 \mathrm{mg}, 2$ $\mathrm{mg}, 1 \mathrm{mg}$ and $0 \mathrm{mg}$ (control) quartz suspended in saline (0.2 $\mathrm{ml}$ ) using a specially designed aerosolizer. Subgroups of 5 rats each were sacrificed on Days 1 and 28 thereafter, and histopathological examination was performed on the lungs. In the quartz treated groups, granulomas were observed at 2 $\mathrm{mg}$ and $4 \mathrm{mg}$, with only mild inflammation was observed at $1 \mathrm{mg}$. A dose of $4 \mathrm{mg}$ does not induce any novel extra alterations, and $1 \mathrm{mg}$ is too weak to cause changes in histopathological parameters on Day 28. A dose of $2 \mathrm{mg}$ quartz was thus suggested to be the most appropriate dose for sensitive detection of acute and subchronic inflammatory changes.

\section{Vehicle Assessment Study (Dry Powder Assessment)}

In our experiments ${ }^{11,18}$, test particles were suspended in saline, but this is associated with considerable agglutination. To prevent this as much as possible, we also tested the efficacy of a dry powder instillation method using a dry powder insufflator without any vehicle ${ }^{34,35}$. A total of 20, 10-week-old male F344 rats were randomly separated into 2 groups of 10 rats each (Fig. 7). Groups 1 and 2 were exposed to $4 \mathrm{mg}$ and $0 \mathrm{mg}$ (air only control) quartz powder, without suspension in any vehicle, and $2 \mathrm{ml}$ air using another type of aerolizer, the DP-4 Insufflator (dry powder insufflator, Penn Century, PA, USA), and sacrificed on Days 1 and 28 thereafter. Histopathological examination revealed that 4 mg quartz dry powder also caused inflammation, but it was mild compared with the previous experiment result with the same dose suspended in $0.2 \mathrm{ml}$ saline. While the dry powder instillation method may be suitable for experiments requiring dry powder formulations, for example, to increase stability in vaccine studies ${ }^{36}$, instillation by this method may

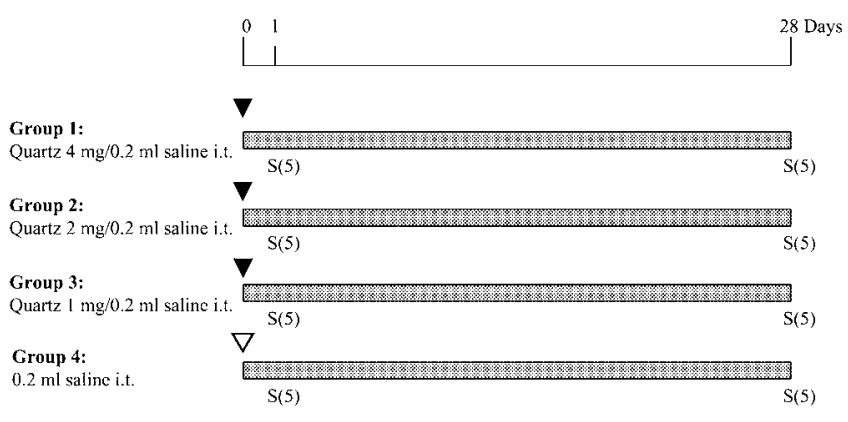

Fig. 6. Experimental design for the dose response study. A total of 40, 10-week-old male F344 rats were randomly separated into 4 groups of 10 rats. $\boldsymbol{\nabla}$, i.t. of $4 \mathrm{mg}, 2 \mathrm{mg}$ or $1 \mathrm{mg} /$ rat quartz suspended in $0.2 \mathrm{ml}$ saline. $\nabla$, i.t. of $0.2 \mathrm{ml}$ saline (control). $\mathrm{S}(5)$, sacrifice of 5 rats.

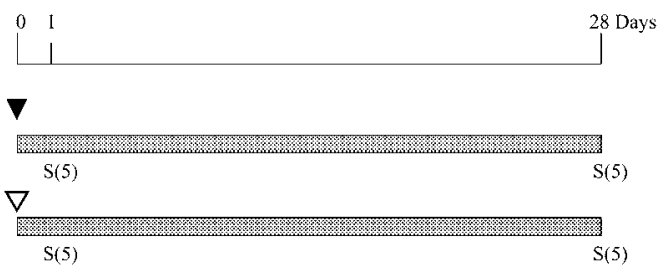

Fig. 7. Experimental design for the vehicle assessment study (dry powder assessment). A total of 20, 10-week-old male F344 rats were randomly separated into 2 groups of 10 rats. $\boldsymbol{\nabla}$, i.t. of $4 \mathrm{mg} / \mathrm{rat}$ quartz powder with $0.2 \mathrm{ml}$ air using a DP-4 Insufflator (dry powder insufflator). $\nabla$, i.t. of $2 \mathrm{ml}$ air (control). S(5), sacrifice of 5 rats.

weaken the effects. Because it is difficult to maintain precise dose and it is impossible to control loss due to expiration air after intratracheal instillation. There are also problems in regard to exposure of researchers since there is possibility of aspiration.

\section{Toxicity Assessment of a Series of Different Particle Types}

The pilot experiments suggested that a dose of $2 \mathrm{mg}$ quartz suspended in $0.2 \mathrm{ml}$ saline was suggested to be most appropriate for sensitive detection of acute and subchronic inflammatory changes. Using this as a control, examination of the toxicity of a series of particles ${ }^{37}$ was performed with our developed bioassay. The materials chosen were 16 particles, including nanoparticles and diesel powders. These materials were selected to perform this validation study and for their variety of characteristics, including shape, composition and particle diameters with the nanometer order or not. Histopathological and immunohistochemical analysis of BrdU incorporation and iNOS were performed after exposure of the lungs.

Experiment 1: A total of 108 rats were randomly separated into 9 groups of 12 animals in each (Fig. 8). Groups 1-4 were exposed by i.t. to $2 \mathrm{mg}$ /rat quartz, titanium 


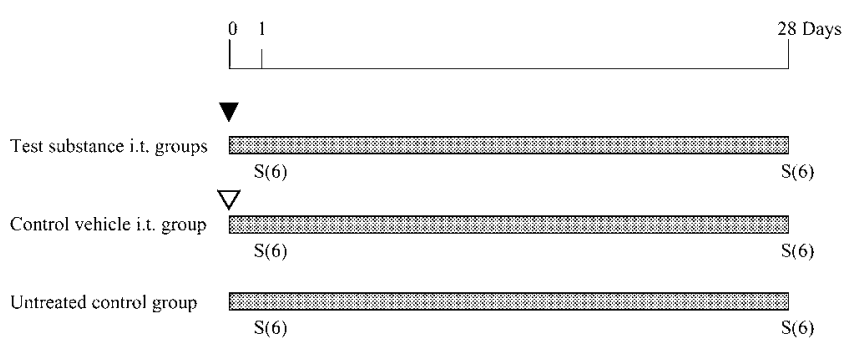

Fig. 8. Experimental design for the toxicity assessment of a series of different particle types (Experiments 1-3). [Experiment 1] $\boldsymbol{\nabla}$, i.t. of $2 \mathrm{mg} /$ rat quartz, titanium dioxide, hydrotalcite or $\beta$ cyclodextrin suspended in $0.2 \mathrm{ml}$ saline or $\mathrm{K}_{2} \mathrm{PdCl}_{4}$ and $\mathrm{Na}_{2} \mathrm{PdCl}_{4}$, suspended in $0.2 \mathrm{ml}$ distilled water. $\nabla$, i.t. of 0.2 $\mathrm{ml}$ saline or distilled water (control). S(6), sacrifice of 6 rats. [Experiment 2] $\mathbf{\nabla}$, i.t. of $2 \mathrm{mg} /$ rat test substances, quartz, titanium dioxide, $\mathrm{CuO}, \mathrm{CuO}$ nanoparticles, $\mathrm{MnO}_{2}, \mathrm{NiO}$ or $\mathrm{NiO}$ nanoparticles suspended in $0.2 \mathrm{ml}$ saline. $\nabla$, i.t. of 0.2 $\mathrm{ml}$ saline (control). S(6), sacrifice of 6 rats. [Experiment 3] $\boldsymbol{\nabla}$, i.t. of $2 \mathrm{mg} /$ rat quartz, diesel standard powder, diesel powder, $\mathrm{C}_{6} \mathrm{H}_{10} \mathrm{O}_{4} \mathrm{Pd}$ or $\mathrm{CaCO}_{3}$ suspended in $0.2 \mathrm{ml}$ saline or neutralized $\mathrm{Na}_{2} \mathrm{PdCl}_{4}$ (final $\mathrm{pH}$ was 6.5) in $20 \mathrm{mM}$ phosphate buffer and $5 \mathrm{~N} \mathrm{NaCl}$. $\nabla$, i.t. of $0.2 \mathrm{ml}$ saline or vehicle of $\mathrm{Na}_{2} \mathrm{PdCl}_{4}$ (control). S(6), sacrifice of 6 rats.

dioxide, hydrotalcite and $\beta$-cyclodextrin suspended in $0.2 \mathrm{ml}$ saline, and Groups 5 and 6 were exposed by i.t. to $2 \mathrm{mg} / \mathrm{rat}$ $\mathrm{K}_{2} \mathrm{PdCl}_{4}$ and $\mathrm{Na}_{2} \mathrm{PdCl}_{4}$ suspended in $0.2 \mathrm{ml}$ distilled water. Distilled water was employed as a vehicle because only the bases, $\mathrm{Na}$ and $\mathrm{K}$, of $\mathrm{K}_{2} \mathrm{PdCl}_{4}$ and $\mathrm{Na}_{2} \mathrm{PdCl}_{4}$ differed. Groups 7-9 were maintained as controls (saline, distilled water or untreated). Subgroups of 6 rats were sacrificed on Days 1 and 28.

Experiment 2: A total of 106 rats were randomly separated into 9 groups (12 rats each in Group 1-8, 10 rats in Group 9). Groups 1-7 were exposed by i.t. to $2 \mathrm{mg} / \mathrm{rat}$ quartz, titanium dioxide, $\mathrm{CuO}, \mathrm{CuO}$ nano, $\mathrm{MnO}_{2}, \mathrm{NiO}$ and $\mathrm{NiO}$ nano suspended in $0.2 \mathrm{ml}$ saline, and Groups 8 and 9 were maintained as controls (saline or untreated). Subgroups of 6 rats were sacrificed on Days 1 and 28.

Experiment 3: A total of 96 rats were randomly separated into 8 groups of 12 rats each. Groups 1-4 and 6 were exposed by i.t. to $2 \mathrm{mg} /$ rat quartz, diesel standard powder, diesel powder, $\mathrm{C}_{6} \mathrm{H}_{10} \mathrm{O}_{4} \mathrm{Pd}$ and $\mathrm{CaCO}_{3}$ suspended in $0.2 \mathrm{ml}$ saline, and Group 5 was exposed to neutralized $\mathrm{Na}_{2} \mathrm{PdCl}_{4}$ (final $\mathrm{pH}$ was 6.5) in $20 \mathrm{mM}$ phosphate buffer and $5 \mathrm{~N} \mathrm{NaCl}$. Groups 7 and 8 were maintained as vehicle controls (saline or vehicle of Group 5). Subgroups of 6 rats were sacrificed on Days 1 and 28.

In order to assess toxicity to lungs for each fine particle material and to screen for hazard in a relatively simple way, toxicity points for each particle or chemical were calculated from histopathological and the immunohistochemical BrdU and iNOS findings (Table 1) and placed in order. More detailed information on total toxicity points has previously been reported by Yokohira et al. ${ }^{37}$. The results of the evaluation of particle toxicity by total toxicity points are outlined below, and summarized results for fine particle

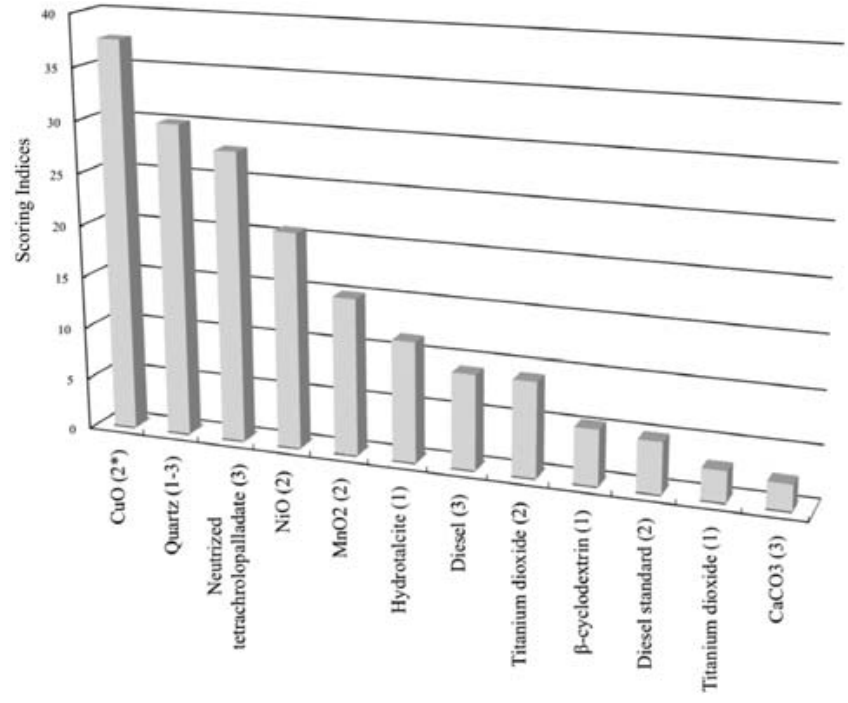

Fig. 9. Results for the fine particle toxicity. *, indicates the experiment number (Experiment 1, 2 or 3). Some materials, including nanoparticles, demonstrated toxicity that was too strong for sensitive assessment. The ranking order is $\mathrm{CuO}>$ quartz $>$ neutralized $\mathrm{Na}_{2} \mathrm{PdCl}_{4}>\mathrm{NiO}>$ hydrotalcite $>\mathrm{MnO}_{2}>$ diesel $>$ titanium dioxide (in Experiment 2) $>\beta$-cyclodextrin $>$ diesel standard $>$ titanium dioxide (in Experiment 1 ) $>$ $\mathrm{CaCO}_{3}$. This figure is modified version of that of Yokohira et al. $2008^{35}$.

toxicity are detailed in Fig. 9. Only $\mathrm{CuO}$ caused greater toxicity than quartz; the other particles had relatively minor effects. Although some materials, including nanoparticles, demonstrated toxicity that was too strong for sensitive assessment, the ranking order could be clarified as follows: $\mathrm{CuO}>$ quartz $>$ neutralized $\mathrm{Na}_{2} \mathrm{PdCl}_{4}>\mathrm{NiO}>$ hydrotalcite $>\mathrm{MnO}_{2}>$ diesel $>$ titanium dioxide (in Experiment 2) $>\beta$ cyclodextrin $>$ diesel standard $>$ titanium dioxide (in Experiment 1) $>\mathrm{CaCO}_{3}$.

The various particles employed in the present study, quartz, titanium dioxide, hydrotalcite and $\beta$-cyclodextrin, $\mathrm{K}_{2} \mathrm{PdCl}_{4}, \mathrm{Na}_{2} \mathrm{PdCl}_{4}, \mathrm{CuO}, \mathrm{CuO}$ nano, $\mathrm{MnO}_{2}, \mathrm{NiO}, \mathrm{NiO}$ nano, diesel standard powder, diesel powder, $\mathrm{C}_{6} \mathrm{H}_{10} \mathrm{O}_{4} \mathrm{Pd}$ and $\mathrm{CaCO}_{3}$, were chosen based on likelihood of human exposure. Hydrotalcite is employed as an antacid, and $\beta$ cyclodextrin is employed as a food additive and in the pharmaceutical field to improve dissolution, chemical stability and bioavailability ${ }^{37-39} \cdot \mathrm{CaCO}_{3}$ is calcium carbonate, is commonly referred to as chalk ${ }^{40}$, and in industrial plants, workers may breathe in $\mathrm{K}_{2} \mathrm{PdCl}_{4}{ }^{41}$, $\mathrm{Na}_{2} \mathrm{PdCl}_{4}^{42}, \mathrm{C}_{6} \mathrm{H}_{10} \mathrm{O}_{4} \mathrm{Pd}$ (the preceding 3 particles are used as catalysers), $\mathrm{CuO}, \mathrm{CuO}$ nanoparticles, $\mathrm{MnO}_{2}, \mathrm{NiO}$ or $\mathrm{NiO}$ nanoparticles. Diesel powder is a problematic air pollutant capable of inducing inflammation ${ }^{43}$.

All rats instilled with $\mathrm{K}_{2} \mathrm{PdCl}_{4}$ or $\mathrm{Na}_{2} \mathrm{PdCl}_{4}$ solution died from severe hemorrhage and edema of the lungs following intratracheal instillation in Experiment $\mathrm{A}$. The $\mathrm{pH}$ values of the $\mathrm{K}_{2} \mathrm{PdCl}_{4}$ and $\mathrm{Na}_{2} \mathrm{PdCl}_{4}$ solutions were strongly acidic at 3.2, and this presumably was a major contributor to 
Table 1. Toxicity Points for Evaluation of Particle Toxicity (Experiments A-C)

\begin{tabular}{|c|c|c|c|c|c|c|}
\hline & \multirow[b]{2}{*}{ Chemicals } & \multirow{2}{*}{$\begin{array}{l}\text { No. of } \\
\text { rats }\end{array}$} & \multirow{2}{*}{ Histopathology ${ }^{\mathrm{a}}$} & \multicolumn{2}{|c|}{ Inmmunohistochemistry $^{\mathrm{b}}$} & \multirow{2}{*}{$\begin{array}{c}\text { Toxicity } \\
\text { points }\end{array}$} \\
\hline & & & & BrdU & iNOS & \\
\hline \multirow[t]{4}{*}{ Experiment 1} & Quartz & 12 & 10.0 & 10.0 & 10.0 & 30.0 \\
\hline & Titanium dioxide & 12 & 2.8 & -0.1 & 0.4 & 3.0 \\
\hline & Hydrotalcite & 12 & 3.3 & 6.3 & 1.9 & 11.5 \\
\hline & $\beta$-cyclodextrin & 12 & 1.8 & 3.5 & 0.1 & 5.4 \\
\hline \multirow[t]{7}{*}{ Experiment 2} & Quartz & 12 & 10.0 & 10.0 & 10.0 & 30.0 \\
\hline & Titanium dioxide & 12 & 3.5 & 3.0 & 2.4 & 8.9 \\
\hline & $\mathrm{CuO}$ & 12 & 11.6 & 18.1 & 7.5 & 37.2 \\
\hline & CuO nano & 0 & $-^{\mathrm{C}}$ & - & - & - \\
\hline & $\mathrm{MnO}_{2}$ & 12 & 4.2 & 0.8 & 5.1 & 10.1 \\
\hline & $\mathrm{NiO}$ & 10 & 7.1 & 2.9 & 4.7 & 14.7 \\
\hline & $\mathrm{NiO}$ nano & 0 & - & - & - & - \\
\hline \multirow[t]{6}{*}{ Experiment 3} & Quartz & 12 & 10.0 & 10.0 & 10.0 & 30.0 \\
\hline & Diesel standard & 12 & 2.1 & 1.6 & 1.2 & 4.9 \\
\hline & Diesel & 12 & 1.9 & 5.0 & 2.2 & 9.1 \\
\hline & $\mathrm{C}_{6} \mathrm{H}_{10} \mathrm{O}_{4} \mathrm{Pd}$ & 0 & - & - & - & - \\
\hline & Neutralized $\mathrm{Na}_{2} \mathrm{PdCl}_{4}$ & 12 & 4.2 & 20.3 & 3.3 & 27.8 \\
\hline & $\mathrm{CaCO}_{3}$ & 12 & 1.0 & 1.0 & 0.4 & 2.4 \\
\hline
\end{tabular}

\footnotetext{
a Points are relative to 10 points (full marks) for quartz derived from the histopathological scoring indices.

b Total points for imunohistopathological changes of BrdU and iNOS derived from labeling indices.

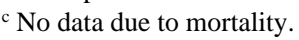

Based on modified from Yokohira et al. $2008^{35}$.
}

lung damage. The lungs instilled with neutralized $\mathrm{Na}_{2} \mathrm{PdCl}_{4}$ also demonstrated severe inflammatory changes on Day 1. The findings for lungs treated with $\mathrm{C}_{6} \mathrm{H}_{10} \mathrm{O}_{4} \mathrm{Pd}$ were almost the same, severe hemorrhage and edema, as those for $\mathrm{K}_{2} \mathrm{PdCl}_{4}$ and $\mathrm{Na}_{2} \mathrm{PdCl}_{4}$. However, the $\mathrm{pH}$ value of the $\mathrm{C}_{6} \mathrm{H}_{10} \mathrm{O}_{4} \mathrm{Pd}$ solution was 4.9 , which was not sufficiently acidic to lead to death. Schmid et al. reported that $\mathrm{PdSO}_{4}$ exerts significant effects on human epithelial lung cells ${ }^{44}$, and we have previously confirmed PdO toxicity in rats ${ }^{18}$. Based on the available results, it is possible that not only strong acids but also palladium itself has toxic potential in the lung.

In the case of $\mathrm{CuO}$ and $\mathrm{NiO}$, the diameters of the particles were in the micrometer and nanometer ranges. With the same volume of material, the nanoparticles of both $\mathrm{CuO}$ and $\mathrm{NiO}$ caused much more severe acute toxicity. In general, it is likely that nanoparticles exert a greater impact because of the area and characteristics of the surfaces ${ }^{45}$. Furthermore, effects may be exerted in secondary sites. For example, an oral administration study in mice indicated that titanium dioxide is retained in the liver, spleen, kidney and lung tissues after uptake through the gastrointestinal tract ${ }^{46}$. However, no remarkable histopathological changes were seen in the liver and kidneys after treatment with nanoparticles of $\mathrm{CuO}$ or $\mathrm{NiO}$ in the present study. Also, $\mathrm{NiO}$ nanoparticles induced only mild inflammatory change in the lungs on Day 1. Toya et al. similarly found limited histopathological effects on the lungs with $13.0 \mathrm{mg} \mathrm{NiO}$ powder $/ \mathrm{kg}$ b.w. ${ }^{47}$. Further examination is necessary to clarify the causes of death observed here.
To establish a bioassay model for detection of lung toxicity due to fine particles for screening purposes, both positive and negative controls are needed. Quartz is known as a typical lung toxic agent ${ }^{48}$ and provides a reliable positive control. Titanium dioxide was classified as belonging to Group 2B (possibly carcinogenic to humans) in a recent International Agency for Research on Cancer (IARC) publication $^{49}$, but Hext et al. concluded from an overview of epidemiology studies and toxicology studies in mice, rats and hamsters that titanium dioxide dust should not exert carcinogenic effects in the human lung ${ }^{50}$. On the other hand, titanium dioxide has carcinogenic potential ${ }^{51}$, and exposure may result in formation of DNA adducts ${ }^{52}$. With earlier assessment of acute or subacute findings, the severity of toxicity differed according to the instilled particles: quartz > 80:20 anatase:rutile and ultrafine titanium dioxide $>$ finesized rutile titanium dioxide $=$ ultrafine rutile titanium dioxide ${ }^{53,54}$. Use of titanium dioxide as a negative control should be considered, where possible, for experimental purposes. In both Experiments 1 and 2, titanium dioxide was employed as a negative control. However, the respective total toxicity points were 3.0 and 8.9. A total point value of 8.9 seems excessively high for a negative control. However, based on the total points in these experiments, at least 3 rough grades of toxicity level, severe, moderate and mild, could be determined. It is expected that further investigations to obtain more particle toxicity data will allow more sensitive assessment of the toxicity of particles in the future. 


\section{Conclusion}

The results of several pilot experiments, performed in rats using quartz as a typical lung toxic particle, suggest that Days 1 and 28 after i.t. of $2 \mathrm{mg}$ of fine test particles suspended in $0.2 \mathrm{ml}$ vehicle are the most appropriate for detection of acute and subacute inflammatory changes, respectively. Furthermore, BrdU on Day 1 and iNOS on Day 28 proved to be suitable end-point markers for this purpose. Examination of the toxicity of a series of particles could be performed with the developed bioassay ${ }^{55}$. Although some materials, including nanoparticles, demonstrated toxicity that was too strong for sensitive assessment, a ranking order could be clarified.

Our bioassay does suffer from a weakness in that even low doses of some particles may lead to death. Further dose range studies are necessary. The i.t. method has been proposed as the most reliable route for assessing the pulmonary toxicity of particles in rodents ${ }^{56}$, although there are biologically different responses to inhalation and instillation $^{30}$.

Another limitation of this bioassay is that the toxicity of particles can only be detected at an early stage because the experimental period is limited to 28 days. In this experiment, a dose response study was performed for quartz, not for risk assessment, but for improvement of the bioassay, and this study was not performed with other test particles. For risk assessment, more experiments, including dose response studies for each test particle with hazard characterization, should be conducted. With in that said, the bioassay was originally designed to be used for hazard identification at an early stage and to rank the toxicities of various particles given at single representative concentrations. The approach adopted clearly is also useful for detection of acute and subacute pulmonary particle characteristics using a histopathological scoring system and markers like BrdU and iNOS for screening purposes.

Acknowledgements: We thank Koji Kato (Nagoya City University Graduate School of Medical Sciences) for technical assistance and Dr. Malcolm A. Moore, a native English-speaking scientist, for help in preparation and critical reading of the manuscript.

\section{References}

1. Ghio AJ and Huang YC. Exposure to concentrated ambient particles (CAPs): a review. Inhal Toxicol. 16: 53-59. 2004.

2. Tjoe-Nij E, Meer Gd G, Smit J, and Heederik D. Lung function decrease in relation to pneumoconiosis and exposure to quartz-containing dust in construction workers. Am J Ind Med. 43: 574-583. 2003.

3. Repine JE, Bast A, and Lankhorst I. Oxidative stress in chronic obstructive pulmonary disease. Oxidative Stress Study Group. Am J Respir Crit Care Med. 156: 341-357. 1997.

4. Linden M, Rasmussen JB, Piitulainen E, Tunek A, Larson $\mathrm{M}$, Tegner $\mathrm{H}$, Venge $\mathrm{P}$, Laitinen LA, and Brattsand R.
Airway inflammation in smokers with nonobstructive and obstructive chronic bronchitis. Am Rev Respir Dis. 148: 1226-1232. 1993.

5. Bowden DH and Adamson IY. The role of cell injury and the continuing inflammatory response in the generation of silicotic pulmonary fibrosis. J Pathol. 144: 149-161. 1984.

6. Benson SC, Belton JC, and Scheve LG. Regulation of lung fibroblast proliferation and protein synthesis by bronchiolar lavage in experimental silicosis. Environ Res. 41: 61-78. 1986.

7. Borm PJ and Tran L. From quartz hazard to quartz risk: the coal mines revisited. Ann Occup Hyg. 46: 25-32. 2002.

8. Davis JM, Ottery J, and le Roux A. The effect of quartz and other non-coal dusts in coalworkers' pneumoconiosis. Part II. Lung autopsy study. Inhaled Part. 4 (Pt 2): 691-702. 1975.

9. Gratzner HG. Monoclonal antibody to 5-bromo- and 5iododeoxyuridine: A new reagent for detection of DNA replication. Science. 218: 474-475. 1982.

10. Castranova V, Porter D, Millecchia L, Ma JY, Hubbs AF, and Teass A. Effect of inhaled crystalline silica in a rat model: time course of pulmonary reactions. Mol Cell Biochem. 234-235: 177-184. 2002.

11. Yokohira M, Takeuchi H, Yamakawa K, Saoo K, Ikeda M, Matsuda Y, Zeng Y, Hosokawa K, Maeta H, and Imaida K. Establishment of a bioassay system for detection of lung toxicity due to fine particle instillation: Sequential histopathological changes with acute and subacute lung damage due to intratracheal instillation of quartz in F344 male rats. J Toxicol Pathol. 18: 13-18. 2005.

12. Zetterberg G, Johansson A, Lundahl J, Lundborg M, Skold CM, Tornling G, Camner P, and Eklund A. Differences between rat alveolar and interstitial macrophages $5 \mathrm{wk}$ after quartz exposure. Am J Physiol. 274: L226-234. 1998.

13. Speyer CL, Neff TA, Warner RL, Guo RF, Sarma JV, Riedemann NC, Murphy ME, Murphy HS, and Ward PA. Regulatory effects of iNOS on acute lung inflammatory responses in mice. Am J Pathol. 163: 2319-2328. 2003.

14. Gaston B, Drazen JM, Loscalzo J, and Stamler JS. The biology of nitrogen oxides in the airways. Am J Respir Crit Care Med. 149: 538-551. 1994.

15. Jenkins DC, Charles IG, Thomsen LL, Moss DW, Holmes LS, Baylis SA, Rhodes P, Westmore K, Emson PC, and Moncada S. Roles of nitric oxide in tumor growth. Proc Natl Acad Sci USA. 92: 4392-4396. 1995.

16. Thomsen LL, Lawton FG, Knowles RG, Beesley JE, Riveros-Moreno V, and Moncada S. Nitric oxide synthase activity in human gynecological cancer. Cancer Res. 54: 1352-1354. 1994.

17. Thomsen LL, Miles DW, Happerfield L, Bobrow LG, Knowles RG, and Moncada S. Nitric oxide synthase activity in human breast cancer. Br J Cancer. 72: 41-44. 1995.

18. Yokohira M, Takeuchi H, Yamakawa K, Saoo K, Matsuda Y, Zeng Y, Hosokawa K, and Imaida K. Bioassay by intratracheal instillation for detection of lung toxicity due to fine particles in F344 male rats. Exp Toxicol Pathol. 58: 211-221. 2007.

19. Renne RA, Smith LG, McDonald KE, Shields CA, Gandolfi AJ, and Lund JE. Morphologic and biochemical effects of intratracheally administered oil shale in rats. J Environ Pathol Toxicol. 3: 397-406. 1980.

20. Kirkegaard T, Hansen A, Bruun E, and Brynskov J. 
Expression and localisation of matrix metalloproteinases and their natural inhibitors in fistulae of patients with Crohn's disease. Gut. 53: 701-709. 2004.

21. Ernst H, Rittinghausen S, Bartsch W, Creutzenberg O, Dasenbrock C, Gorlitz BD, Hecht M, Kairies U, Muhle H, Muller M, Heinrich U, and Pott F. Pulmonary inflammation in rats after intratracheal instillation of quartz, amorphous $\mathrm{SiO} 2$, carbon black, and coal dust and the influence of poly2-vinylpyridine-N-oxide (PVNO). Exp Toxicol Pathol. 54: 109-126. 2002.

22. Pott F and Stober W. Carcinogenicity of airborne combustion products observed in subcutaneous tissue and lungs of laboratory rodents. Environ Health Perspect. 47: 293-303. 1983.

23. Mohr U, Ernst H, Roller M, and Pott F. Pulmonary tumor types induced in Wistar rats of the so-called "19-dust study". Exp Toxicol Pathol. 58: 13-20. 2006.

24. Ikegami T, Tanaka AK, Taniguchi M, Clark ML, Ragan HA, Mast TJ, and Lee KP. Chronic inhalation toxicity and carcinogenicity study on potassium octatitanate fibers (TISMO) in rats. Inhal Toxicol. 16: 291-310. 2004.

25. Friemann J, Pott F, Wilk KB, Ahrens O, Rosenbruch M, Hilscher W, and Schlipkoter HW. Pulmonary alveolar proteinosis in rats after administration of quartz: its possible role in morphogenesis of lung cancer. $\mathrm{J}$ Cancer Res Clin Oncol. 120: 348-353. 1994.

26. Albrecht C, Schins RP, Hohr D, Becker A, Shi T, Knaapen $\mathrm{AM}$, and Borm PJ. Inflammatory time course after quartz instillation: role of tumor necrosis factor-alpha and particle surface. Am J Respir Cell Mol Biol. 31: 292-301. 2004.

27. Li XY, Brown D, Smith S, MacNee W, and Donaldson K. Short-term inflammatory responses following intratracheal instillation of fine and ultrafine carbon black in rats. Inhal Toxicol. 11: 709-731. 1999.

28. Driscoll KE, Carter JM, Howard BW, Hassenbein DG, Pepelko W, Baggs RB, and Oberdorster G. Pulmonary inflammatory, chemokine, and mutagenic responses in rats after subchronic inhalation of carbon black. Toxicol Appl Pharmacol. 136: 372-380. 1996.

29. Mercer RR, Wang L, Antonini JM, Scabilloni JF, Vallyathan $\mathrm{V}$, and Castranova V. Induction of stromelysin by pulmonary instillation of toxic dust. Paper presented at the Society of Toxicology, 2003.

30. Osier $\mathbf{M}$ and Oberdorster $\mathrm{G}$. Intratracheal inhalation vs intratracheal instillation: differences in particle effects. Fundam Appl Toxicol. 40: 220-227. 1997.

31. Sayes CM, Reed KL, and Warheit DB. Assessing toxicity of fine and nanoparticles: comparing in vitro measurements to in vivo pulmonary toxicity profiles. Toxicol Sci. 97: 163180. 2007.

32. Zhang DD, Hartsky MA, and Warheit DB. Time course of quartz and $\mathrm{TiO}(2)$ particle-induced pulmonary inflammation and neutrophil apoptotic responses in rats. Exp Lung Res. 28: 641-670. 2002.

33. Zhang Q, Kusaka Y, Sato K, Nakakuki K, Kohyama N, and Donaldson K. Differences in the extent of inflammation caused by intratracheal exposure to three ultrafine metals: role of free radicals. J Toxicol Environ Health A. 53: 423438. 1998.

34. Suarez S, O’Hara P, Kazantseva M, Newcomer CE, Hopfer R, McMurray DN, and Hickey AJ. Airways delivery of rifampicin microparticles for the treatment of tuberculosis. $\mathrm{J}$
Antimicrob Chemother. 48: 431-434. 2001.

35. Bot AI, Tarara TE, Smith DJ, Bot SR, Woods CM, and Weers JG. Novel lipid-based hollow-porous microparticles as a platform for immunoglobulin delivery to the respiratory tract. Pharm Res. 17: 275-283. 2000.

36. LiCalsi C, Christensen T, Bennett JV, Phillips E, and Witham C. Dry powder inhalation as a potential delivery method for vaccines. Vaccine. 17: 1796-1803. 1999.

37. Yokohira M, Kuno T, Yamakawa K, Hosokawa K, Matsuda Y, Hashimoto N, Suzuki S, Saoo K, and Imaida K. Lung toxicity of 16 fine particles on intratracheal instillation in a bioassay model using f344 male rats. Toxicol Pathol. 36: 620-631. 2008.

38. Hirayama F and Uekama K. Cyclodextrin-based controlled drug release system. Adv Drug Deliv Rev. 36: 125-141. 1999.

39. Monnaert V, Tilloy S, Bricout H, Fenart L, Cecchelli R, and Monflier E. Behavior of alpha-, beta-, and gammacyclodextrins and their derivatives on an in vitro model of blood-brain barrier. J Pharmacol Exp Ther. 310: 745-751. 2004.

40. Zhang Q and Huang X. Addition of calcite reduces iron's bioavailability in the Pennsylvania coals-potential use of calcite for the prevention of coal workers' lung diseases. $\mathrm{J}$ Toxicol Environ Health A. 68: 1663-1679. 2005.

41. Omrani H, Cavagnat R, and Sourisseau C. A vibrational study of various $\mathrm{K} 2 \mathrm{PdCl}(4-\mathrm{x}) \mathrm{Br}(\mathrm{x})$ solid solutions. Spectrochim Acta A Mol Biomol Spectrosc. 56A: 16451652. 2000.

42. Maiti N, Pal S, and Chattopadhyay S. Reaction of 2(phenylazo)aniline with $\mathrm{Na}_{2} \mathrm{PdCl}_{4}$ : formation of a 2(phenylazo)imino complex of bivalent palladium. Inorg Chem. 40: 2204-2205. 2001.

43. Folkmann JK, Risom L, Hansen CS, Loft S, and Moller P. Oxidatively damaged DNA and inflammation in the liver of dyslipidemic ApoE(-/-) mice exposed to diesel exhaust particles. Toxicology. 237: 134-144. 2007.

44. Schmid M, Zimmermann S, Krug HF, and Sures B. Influence of platinum, palladium and rhodium as compared with cadmium, nickel and chromium on cell viability and oxidative stress in human bronchial epithelial cells. Environ Int. 33: 385-390. 2007.

45. Powers KW, Brown SC, Krishna VB, Wasdo SC, Moudgil $\mathrm{BM}$, and Roberts SM. Research strategies for safety evaluation of nanomaterials. Part VI. Characterization of nanoscale particles for toxicological evaluation. Toxicol Sci. 90: 296-303. 2006.

46. Wang J, Zhou G, Chen C, Yu H, Wang T, Ma Y, Jia G, Gao Y, Li B, Sun J, Li Y, Jiao F, Zhao Y, and Chai Z. Acute toxicity and biodistribution of different sized titanium dioxide particles in mice after oral administration. Toxicol Lett. 168: 176-185. 2007.

47. Toya T, Serita F, Sawatari K, and Fukuda K. Lung lesions induced by intratracheal instillation of nickel fumes and nickeloxide powder in rats. Ind Health. 35: 69-77. 1997.

48. Bruch J, Rehn B, Song W, Gono E, and Malkusch W. Toxicological investigations on silicon carbide. 2. In vitro cell tests and long term injection tests. Br J Ind Med. 50: 807-813. 1993.

49. IARC Monograph. 93: 1-5. 2006.

50. Hext PM, Tomenson JA, and Thompson P. Titanium dioxide: inhalation toxicology and epidemiology. Ann 
Occup Hyg. 49: 461-472. 2005.

51. Lee KP, Trochimowicz HJ, and Reinhardt CF. Pulmonary response of rats exposed to titanium dioxide (TiO2) by inhalation for two years. Toxicol Appl Pharmacol. 79: 179192. 1985.

52. Gallagher J, Heinrich U, George M, Hendee L, Phillips DH, and Lewtas J. Formation of DNA adducts in rat lung following chronic inhalation of diesel emissions, carbon black and titanium dioxide particles. Carcinogenesis. 15: 1291-1299. 1994

53. Warheit DB, Hoke RA, Finlay C, Donner EM, Reed KL, and Sayes CM. Development of a base set of toxicity tests using ultrafine $\mathrm{TiO}(2)$ particles as a component of nanoparticle risk management. Toxicol Lett. 171: 99-110. 2007.
54. Warheit DB, Webb TR, Reed KL, Frerichs S, and Sayes CM. Pulmonary toxicity study in rats with three forms of ultrafine-TiO2 particles: differential responses related to surface properties. Toxicology. 230: 90-104. 2007.

55. Yokohira M, Kuno T, Yamakawa K, Hosokawa K, Matsuda Y, Hashimoto N, Suzuki S, Saoo K, and Imaida K. Lung Toxicity of 16 Fine Particles on Intratracheal Instillation in a Bioassay Model Using F344 Male Rats. Toxicol Pathol. 36: 620-631. 2008.

56. Warheit DB, Brock WJ, Lee KP, Webb TR, and Reed KL. Comparative pulmonary toxicity inhalation and instillation studies with different $\mathrm{TiO} 2$ particle formulations: impact of surface treatments on particle toxicity. Toxicol Sci. 88: 514524. 2005. 